Original Research

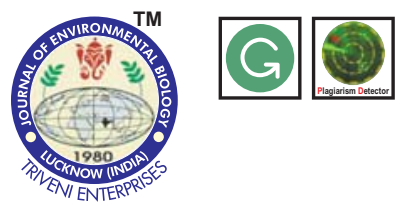

DOI: https://doi.org/10.22438/jeb/38/3/MRN-404

\title{
Assessment of natural radionuclides and chemical constituents in commonly used hair dyes in Saudi Arabia
}

ISSN: 0254-8704 (Print)

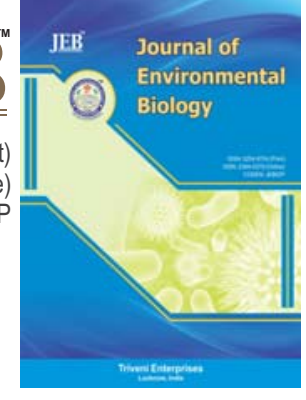

\section{Authors Info}

\section{W. R. Alharbi}

Department of Physics, Faculty of Science, King Abdulaziz University, Jeddah-21432, Saudi Arabia

${ }^{*}$ Corresponding Author Email : walharbi@kau.edu.sa

Key words

Activity concentrations, Chemical composition, HPGe spectrometer, Radiological hazard

\section{Publication Info}

Paper received : 12.07 .2016

Revised received : 31.10 .2016

Re-revised received : 30.01 .2017

Accepted : 01.03.2017

\section{Abstract}

Aim: Use of hair dyes has dramatically increased throughout the world, so there is an urgent need to human awareness of the radiological hazard potentially arising by using hair dyes periodically to reducing of use them. The main objective of the study was to estimate the radiological risk due to natural radionuclides and chemical constituents from the most common of hair dyes received by the consumer in SaudiArabia.

Methodology: A total of fifty- one sample of seventeen hair dyes with common usage in Saudi Arabia imported from different countries. Radionuclides $\left({ }^{40} \mathrm{~K},{ }^{232} \mathrm{Th},{ }^{226} \mathrm{Ra}\right.$ and $\left.{ }^{238} \mathrm{U}\right)$ in blonde, brown and black hair dyes were determined HPGe spectrometer. Twenty-four elements and their oxide concentrations were determined using ARL QUANT'X Energy-Dispersive X-ray Fluorescence spectrometer.

Results: The mean concentrations of ${ }^{40} \mathrm{~K}$ in blonde dyes was above the permissible limit. Others naturally occurring radionuclides were found to have mean activity concentrations below the permissible limit. Uranium-238 was present in measurable values in most samples. The calculated radiological hazard, Absorbed dose rate, Annual effected dose rate and Radium equivalent for all samples were below the recommended value, except in one blonde dye sample. Most elements exceeded the reference level.

Interpretation: This is the first study for determining the radiological risks associated with usage the hair dyes (black, brown and blonde). From these measurements, it can be concluded that it should avoid the use of hair dyes periodically. Further, the obtained results will be of interest to those involved in health research through to compiling evidence on the subject
Main goal:

Assessment of natural radionuclides and chemical risk in fifty-one samples of blonde, brown and black hair dyes, which were purchased from local market of Saudi Arabia.

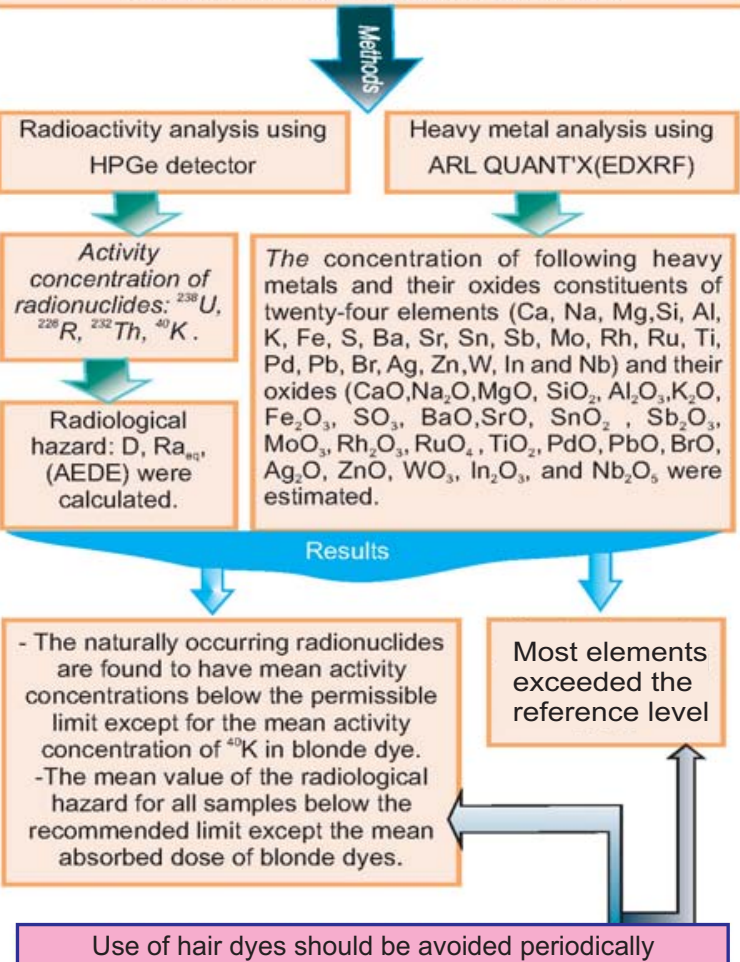




\section{Introduction}

The use of hair dyes has been traced back to thousands of years. Herbal dyes are generally safe, specifically Henna, Buxus dioica and Isatis (Nohynek et al., 2004), but various health problems arises due to use of these chemical dyes, Commercial hair dyes are poor in quality and highly toxic (Haluk et al., 2014). Some dye manufacturing companies may manipulate the consumer's health and add the synthetic organic compounds for coloration. Ammonia present in the chemical dyes open the hair cuticle to facilitate the oxidation process that lightens the natural color of the hair and it also helps in developing the added color. Hair dyes are amongst the most problematic pollutants because of their toxic effect on humans (Nohynek et al., 2004; Gaffar et al., 2014). The radiological risk in natural hair dyes come mainly from natural radionuclides ${ }^{238} \mathrm{U},{ }^{232} \mathrm{Th}$ series and ${ }^{40} \mathrm{~K}$ through transmission of radionuclides from soil to plants (Chakraborty et al., 2013).

Determination of radioactivity in hair dyes is important for human health (Pietrzak-Flis et al., 2001). As these hair dyes contain chemicals like $p$-phenylenediamine, hydrogen peroxide and resorcinol (Fernández-Vozmediano et al., 2011; Al-Suwaidi and Ahmed, 2010). They can cause rash and dermatitis of eyes, throat, scalp, skin and respiratory system, hence while using them safety glasses, gloves, and good ventilation is essential. The dark colored dyes are more Toxic as they contain higher level of chemicals (Broides et al., 2011; Le Coz et al., 2000). Some hair dye products have been found to contain mutagenic \& carcinoge nic compounds. Coal tar colors are derived from the tar found in bituminous coal. Some coal tar colors also contain heavy metals. In view of the above, the present study was carried out to estimate the radiological risks due to natural radionuclides and chemical constituents from the most common hair dyes used in Saudi Arabia.

\section{Materials and Methods}

Sample preparation and assessment of radioactivity : A total of fifty one samples of seventeen hair dyes of blonde, brown and black color were purchased from local market of Saudi Arabia and numbered as Hd1- Hd5 (blonde), Hd6-Hd 11(brown) and Hd12$\mathrm{Hd} 17$ (black), respectively. The samples were dried at $110^{\circ} \mathrm{C}$. The homogenized powdered samples stored in Marinelli beaker were sealed for about one month to get secular equilibrium for ${ }^{222} \mathrm{Rn}$ and ${ }^{226} \mathrm{Ra}$. Radioactivity was assessed by high resolution $\mathrm{y}$ ray spectrometry HPGe detector with $25 \%$ counting efficiency and high resolution of $1.29 \mathrm{keV}$ (FWHM). at $662 \mathrm{keV}$ and $1.70 \mathrm{keV}$ (FWHM) Counting of the samples and background were carried out for $10 \mathrm{hrs}$. Each sample was measured at the same time for about $10 \mathrm{hrs}$.

The gamma background level was estimated with an empty polyethylene Marinelli beaker. The background was measured under similar above mentioned conditions. The net peak count rate of each sample was obtained by subtracting the gamma ray background. The energy and efficiency of gamma spectrometer was calibrated using standard sources: ${ }^{232} \mathrm{Th},{ }^{152} \mathrm{Eu}$, ${ }^{226} \mathrm{Ra}$, and mixed source (containing ${ }^{57} \mathrm{Co},{ }^{241} \mathrm{Am},{ }^{60} \mathrm{Co}, 88 \mathrm{Y}, 85 \mathrm{Sr}$, ${ }^{137} \mathrm{Cs}{ }^{109} \mathrm{Cd},{ }^{203} \mathrm{Hg}$ and ${ }^{138} \mathrm{Ce}$ ) (Bajoga et al., 2015). The activity concentration of ${ }^{226} \mathrm{Ra}$ and ${ }^{232} \mathrm{Th}$ was determined assuming the following gamma lines: $1764 \mathrm{keV}, 11220 \mathrm{keV}, 609 \mathrm{keV}$ and 351 keV of ${ }^{214} \mathrm{Bi}$ and $186 \mathrm{keV}$ of ${ }^{222} \mathrm{Rn}$ for ${ }^{226} \mathrm{Ra}, 860 \mathrm{keV}$ and $582 \mathrm{keV}$ of ${ }^{208} \mathrm{Ti}, 968 \mathrm{keV}, 911 \mathrm{keV}, 338 \mathrm{keV}$, for ${ }^{228} \mathrm{Ac}$ and $238 \mathrm{keV}$ of ${ }^{212} \mathrm{~Pb}$ for ${ }^{232} \mathrm{Th}$. The activity concentration of ${ }^{40} \mathrm{~K}$ was determined using a single peak area of $1460 \mathrm{keV}$ (Chandrashekara and Somashekarappa, 2016).

The absorbed dose rate $\left(D_{R}\right)$ in air from external gamma radiation at $1 \mathrm{~m}$ above ground level due to the presence of uniformly distributed natural radionuclides in measured soils was calculated by the following formula (Beretka and Mathew, 1985): $\mathrm{DR}(\mathrm{nGy} / \mathrm{h})=0.0417 \mathrm{CK}+0.462 \mathrm{CU}+0.604 \mathrm{CTh}(1)$.

Where, $\mathrm{C}_{K}, \mathrm{C}_{U}$, and $\mathrm{C}_{\mathrm{Th}}$ are the activity concentrations (in $\mathrm{Bqkg}^{-1}$ ) for ${ }^{40} \mathrm{~K},{ }^{238} \mathrm{U}$ and ${ }^{232} \mathrm{Th}$, respectively. Secular equilibrium was assumed for dose calculation. To assess the radiological hazard due to natural radionuclide ${ }^{40} \mathrm{~K},{ }^{232} \mathrm{Th}$ and ${ }^{238} \mathrm{U}$, radium equivalent activity was calculated by the following formula (Abdul hussein et al., 2016):

$\operatorname{Ra}_{\text {eq }}\left(B q k g{ }^{-1}\right)=C_{R a}+1.43 C_{\text {Th }}+0.077 \mathrm{CK} \ldots \ldots$ (2) where, $C_{K}, C_{\text {Th }}$ and $\mathrm{C}_{\mathrm{Ra}}$ are the specific activities of ${ }^{40} \mathrm{~K},{ }^{232} \mathrm{Th}$ and ${ }^{226} \mathrm{Ra}$ in $\mathrm{Bqkg}{ }^{-1}$. To evaluate the radiological hazard for consumers, indoor Annual Effective Dose Rate (AEDR) indoor was calculated by the following formula, considering indoor time occupancy factor as $80 \%$ ( Saleh and El-Taher, 2016) AEDR (mSv/yr) = DR × 10-6 (mGy/h) $\times 8760$ $(\mathrm{h} / \mathrm{yr}) \times 0.7(\mathrm{~Sv} / \mathrm{Gy}) \times 0.8 \ldots \ldots .(3)$ where, $0.7 \mathrm{~Sv} / \mathrm{Gy}$ was taken as conversion factor.

Heavy metal analysis : The concentration of following heavy metals and their oxides were estimated: $\mathrm{Ca}, \mathrm{Na}, \mathrm{Mg}, \mathrm{Si}, \mathrm{Al}, \mathrm{K}, \mathrm{Fe}, \mathrm{S}$, $\mathrm{Ba}, \mathrm{Sr}, \mathrm{Sn}, \mathrm{Sb}, \mathrm{Mo}, \mathrm{Rh}, \mathrm{Ru}, \mathrm{Ti}, \mathrm{Pd}, \mathrm{Pb}, \mathrm{Br}, \mathrm{Ag}, \mathrm{Zn}, \mathrm{W}, \mathrm{In}, \mathrm{Nb}, \mathrm{Na}_{2} \mathrm{O}$, $\mathrm{MgO}, \mathrm{Al}_{2} \mathrm{O}_{3}, \mathrm{SiO}_{2}, \mathrm{SO}_{3}, \mathrm{~K} \mathrm{O}, \mathrm{CaO}, \mathrm{TiO}_{2}, \mathrm{Fe}_{2} \mathrm{O}_{3}, \mathrm{ZnO}, \mathrm{SrO}, \mathrm{Bro}, \mathrm{Pbo}$, $\mathrm{Nb}_{2} \mathrm{O}_{5}, \mathrm{MoO}_{3}, \mathrm{RuO}_{4}, \mathrm{Rh}_{2} \mathrm{O}_{3}, \mathrm{PdO}, \mathrm{Ag}_{2} \mathrm{O}, \mathrm{In}_{2} \mathrm{O}_{3}, \mathrm{SnO} 2, \mathrm{Sb}_{2} \mathrm{O}_{3}, \mathrm{BaO}$ and $\mathrm{WO}_{3}$ by ARL QUANT'X Energy-Dispersive X-ray Fluorescence spectrometer (EDXRF). EDXRF provides a rapid and nondestructive method for the analysis of major and trace elements of across the broadest range of samples, including bulk solids, granules, powders, thin films, liquids, geological and biological samples. To detect the X-rays characteristic, a Peltier-cooled Si (Li) detector (PCD) with 15 re5eV FWHMsolution for $5.9 \mathrm{keV} X$-rays at $1,500 \mathrm{cps}$ and Beryllium (Be) Window $\leq 7.6$ micron ( 0.3 mil) was used. The data acquisition was employed by using Multi-Channel Analyzer '32-bit, 4096 channel MCA (Budaka et al., 2006). The samples were dried at $60^{\circ} \mathrm{C}$ in an oven. The powder obtained was sieved through a 300 mesh sieve and the samples were then transferred onto a polyethylene myler film. A circular sample radius of approximately $3 \mathrm{~cm}$ was used. All the measurements were obtained by running each sample three times. The average concentration was obtained from the mean values of peak area. 

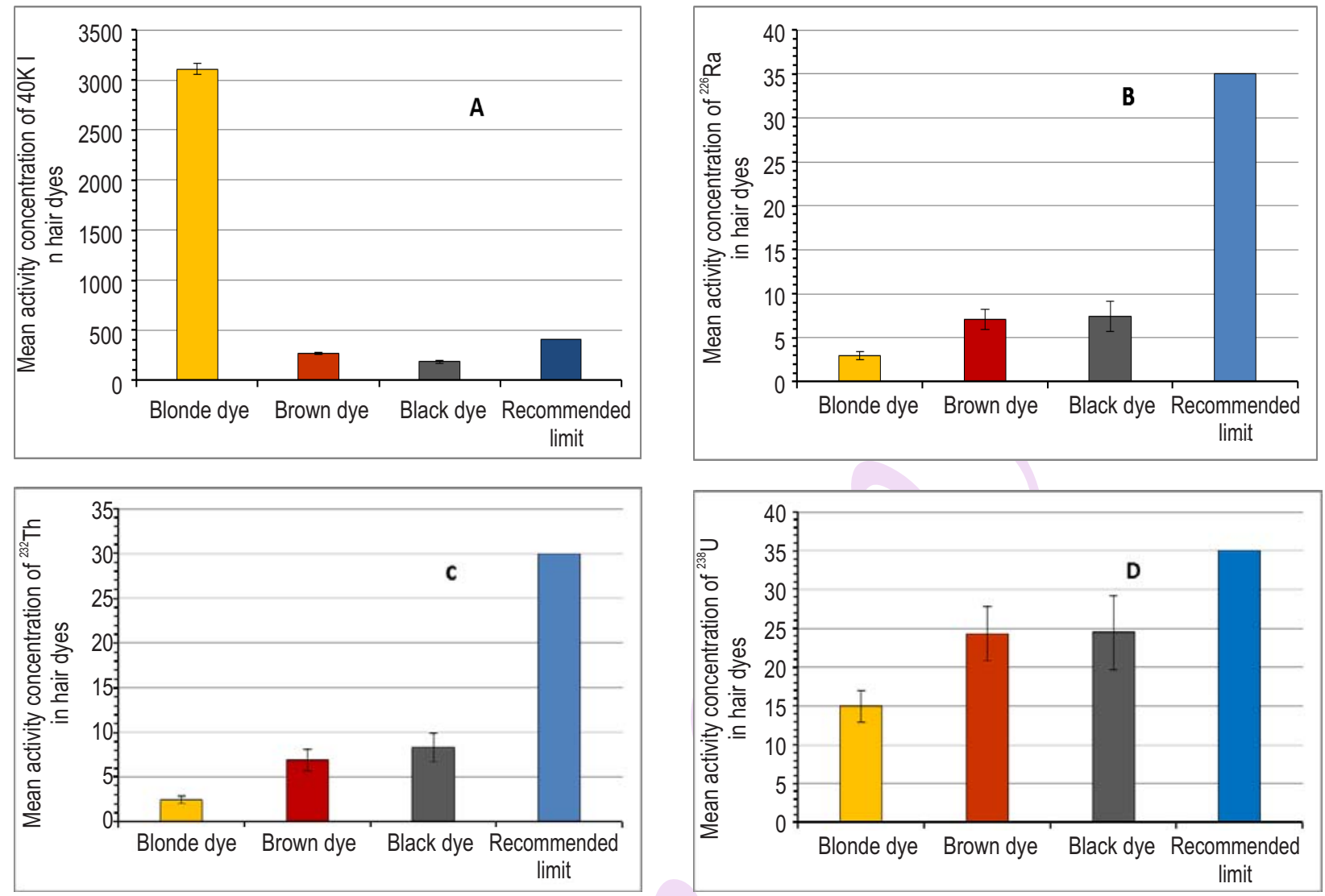

Fig. 1 : Comparison between the mean activity concentration of natural radionuclides in studied samples with the recommended limit (UNSCEAR, 2000)

\section{Results and Discussion}

Activity concentration in hair dye samples $\left(\mathrm{Bq}^{-1} \mathrm{~g}^{-1}\right)$ : The average activity concentration due to ${ }^{238} \mathrm{U},{ }^{226} \mathrm{R},{ }^{232} \mathrm{Th},{ }^{40} \mathrm{~K}$ radionuclides in brown, black hair and blonde hair dyes is given in Table1. Abdel Ghany et al.(2014) estimated radioactivity in textile dyes. The mean activity concentration of ${ }^{40} \mathrm{~K},{ }^{232} \mathrm{Th}$ and ${ }^{238} \mathrm{U}$ were $565,1.15$ and $29.37 \mathrm{~Bq} \mathrm{~kg}^{-1}$, respectively. The absorbed dose rates were below the maximum admissible value, except for yellow dye sample (166 nGy/h). Also, the radium equivalents for all the studied samples were lower than the International recommended limit $\left(35,35,30,400 \mathrm{Bqkg}^{-1}\right.$ for ${ }^{238} \mathrm{U}, 226 \mathrm{Ra}, 232 \mathrm{Th}$ and ${ }^{40} \mathrm{~K}$, respectively) (UNSCEAR, 2000).

A comparison between the mean activity concentration of natural radionuclides in the studied samples with the International recommended limit is shown in Fig.1 (A-D). The average activity concentrations of ${ }^{40} \mathrm{~K},{ }^{226} \mathrm{Ra}$ and ${ }^{232} \mathrm{Th}$ in blonde samples varied from ND to $6767.23 \mathrm{Bqkg}^{-1}$, ND to $5.86 \mathrm{Bqkg}^{-1}$ and ND to $5.50 \mathrm{~Bq}$ $\mathrm{kg}^{-1}$. The results were found to be lower than the global median activity concentration of ${ }^{226} \mathrm{Ra}$ and ${ }^{232} \mathrm{Th}$, respectively. Moreover, from Table1, it can be observed that the maximum of average activity concentration due to ${ }^{40} \mathrm{~K}$ in sample $\mathrm{Hd} 1, \mathrm{Hd} 4$ and $\mathrm{Hd} 5$ was about 11,17 and 10.7 times higher than the global median activity concentrations of ${ }^{40} \mathrm{~K}$. The average activity concentration of brown and black dyes was below the maximum worldwide values. The concentration of ${ }^{40} \mathrm{~K}$ was also below the maximum worldwide acceptable values, except for $\mathrm{Hd} 8, \mathrm{Hd} 9$ and $\mathrm{Hd} 14$ dye samples, which was about $28.5 \%, 14.5 \%$ and $14 \%$ higher than the maximum permissible limit. As observed from Table $2,{ }^{238} \mathrm{U}$ average concentrations ranged from ND to $27.72 \mathrm{Bqkg}^{-1}$ in blonde dyes, 8.18to $41.37 \mathrm{Bqkg}^{-1}$ in brown dyes and 8.18 to $27.26 \mathrm{Bqkg}^{-1}$ in black samples, respectively. All the values were lower than the permissible limit (35 Bqkg ${ }^{-1}$ ), except for sample Hd9 (41.37 $\left.\mathrm{Bqkg}^{-1}\right)$. A slight decrease in the mean activity concentration of ${ }^{226} \mathrm{Ra}$ and ${ }^{232}$ Th was noted in brown hair dyes than in black hair dyes.

The estimated absorbed dose rate (Table 2) ranged from 3.12 to $186.47 \mathrm{nGyh}^{-1}$ in different hair dye samples. An increased dose rate was noted in blonde samples Hd1 (186.47), Hd4 (283.33) and Hd5 (180.80 nGyh $\left.{ }^{-1}\right)$ due to higher radioactivity of ${ }^{40} \mathrm{~K}$. These values were higher than the permissible limit of 55 nGyh $^{-1}$ (UNSCEAR, 2000). Therefore, the impact of radiation exposure on the workers and consumers for these samples cannotbe ignored.

As tabulated in Table 2, radium equivalent activity varied from 7.09 to $523.53 \mathrm{Bqkg}^{-1}$. The highest value was detected in sample $\mathrm{Hd} 4$, which was $41.5 \%$ higher than the safety limit of 370 
Table 1: Average activity concentrations of 238U 226Ra, 232Th and $40 \mathrm{~K}$ in hair dye samples

\begin{tabular}{lllll}
\hline $\begin{array}{l}\text { Sample } \\
\text { code }\end{array}$ & ${ }^{238} \mathrm{U}$ & ${ }^{226} \mathrm{Ra}$ & ${ }^{232} \mathrm{Th}$ & ${ }^{40} \mathrm{~K}$ \\
\hline $\mathrm{Hd} 1$ & $23.67 \pm 3.44$ & $3.58 \pm 0.60$ & $\mathrm{ND}$ & $4411.84 \pm 95.58$ \\
Hd2 & $8.27 \pm 1.72$ & $5.86 \pm 0.82$ & $5.50 \pm 0.79$ & $82.65 \pm 7.01$ \\
Hd3 & $15.24 \pm 1.92$ & $2.94 \pm 0.44$ & $2.92 \pm 0.45$ & $\mathrm{ND}$ \\
Hd4 & $27.72 \pm 3.04$ & $2.45 \pm 0.40$ & $\mathrm{ND}$ & $6767.23 \pm 100.60$ \\
Hd5 & $\mathrm{ND}$ & $\mathrm{ND}$ & $3.82 \pm 0.57$ & $4280.36 \pm 80.66$ \\
Mean & $14.98 \pm 2.03$ & $2.97 \pm 0.45$ & $2.448 \pm 0.36$ & $3108.42 \pm 56.77$ \\
Hd6 & $30.34 \pm 4.04$ & $3.46 \pm .75$ & $2.53 \pm 0.31$ & $20.67 \pm 2.62$ \\
Hd7 & $26.63 \pm 3.11$ & $5.96 \pm 0.71$ & $4.25 \pm 0.50$ & $12.59 \pm 1.40$ \\
Hd8 & $23.45 \pm 3.90$ & $10.55 \pm 1.90$ & $7.85 \pm 1.17$ & $513.91 \pm 25.23$ \\
Hd9 & $41.37 \pm 6.90$ & $6.64 \pm 0.48$ & $10.72 \pm 1.74$ & $458.01 \pm 17.44$ \\
Hd10 & $15.87 \pm 1.43$ & $9.43 \pm 1.54$ & $10.07 \pm 2.11$ & $311.00 \pm 15.44$ \\
Hd11 & $8.18 \pm 1.20$ & $6.49 \pm 1.20$ & $6.04 \pm 1.25$ & $304.64 \pm 13.11$ \\
Mean & $24.31 \pm 3.43$ & $7.09 \pm 1.10$ & $6.91 \pm 1.18$ & $270.14 \pm 12.48$ \\
Hd12 & $23.16 \pm 5.60$ & $8.69 \pm 2.46$ & $11.70 \pm 1.16$ & $341.76 \pm 20.18$ \\
Hd13 & $26.79 \pm 4.20$ & $3.97 \pm 0.91$ & $3.07 \pm 0.29$ & $\mathrm{DN}$ \\
Hd14 & $27.26 \pm 5.61$ & $10.49 \pm 2.51$ & $13.60 \pm 3.51$ & $455.86 \pm 23.21$ \\
Hd15 & $23.80 \pm 4.03$ & $4.43 \pm 0.53$ & $3.32 \pm 0.43$ & $15.91 \pm 2.03$ \\
Hd16 & $22.98 \pm 4.51$ & $8.00 \pm 2.01$ & $16.45 \pm 2.51$ & $284.74 \pm 13.51$ \\
Hd17 & $22.70 \pm 4.51$ & $8.87 \pm 1.71$ & $7.96 \pm 1.41$ & $10.50 \pm 1.71$ \\
Mean & $24.45 \pm 4.74$ & $7.41 \pm 1.69$ & $8.33 \pm 1.55$ & $184.80 \pm 10.11$ \\
\hline
\end{tabular}

ND : Not detectable

Table. 2 : Radiological hazard effects: Absorbed dose rates (D), Radium equivalent activity (Raeq) and Annual effective dose rate $(\mathrm{AEDE})_{\text {indoor }}$

\begin{tabular}{llll}
\hline $\begin{array}{l}\text { Sample } \\
\text { code }\end{array}$ & $\begin{array}{l}\mathbf{D}_{R} \\
\left(\mathbf{n G y ~ h}{ }^{-1}\right.\end{array}$ & $\begin{array}{l}\mathbf{R a}_{\text {eq }} \\
\left(\mathbf{B q ~ k g}^{-1}\right)\end{array}$ & $\begin{array}{l}(\mathbf{A E D E})_{\text {indoor }} \\
\left(\mathbf{m S v y}^{-1}\right)\end{array}$ \\
\hline $\mathrm{Hd} 1$ & 186.47 & 345.30 & 0.92 \\
$\mathrm{Hd} 2$ & 9.48 & 20.08 & 0.05 \\
$\mathrm{Hd} 3$ & 3.12 & 7.12 & 0.02 \\
$\mathrm{Hd} 4$ & 283.33 & 523.53 & 1.39 \\
Hd5 & 180.80 & 335.05 & 0.89 \\
Mean & 132.64 & 246.22 & 0.66 \\
Hd6 & 3.99 & 8.67 & 0.02 \\
Hd7 & 5.85 & 13.00 & 0.03 \\
Hd8 & 31.05 & 61.35 & 0.15 \\
Hd9 & 28.64 & 57.24 & 0.14 \\
Hd10 & 19.05 & 38.45 & 0.10 \\
Hd11 & 19.35 & 38.59 & 0.10 \\
Mean & 17.99 & 36.22 & 0.09 \\
Hd12 & 25.34 & 51.74 & 0.13 \\
Hdd13 & 3.17 & 0.09 & 0.02 \\
Hd14 & 32.08 & 65.04 & 0.16 \\
Hd15 & 4.72 & 10.40 & 0.03 \\
Hd16 & 25.51 & 53.45 & 0.13 \\
Hd17 & 9.35 & 21.06 & 0.05 \\
Mean & 16.70 & 34.80 & 0.09 \\
\hline
\end{tabular}

$\mathrm{Bqkg}^{-1}$. All the other estimated values were less than the permissible limit. Table 2 summarizes the results of the annual effective dose rate. The annual indoor effective dose rate ranged from 0.02- $1.39 \mathrm{mSvy}^{-1}, 0.02-0.15$ and $0.02-0.16$ in blonde, brown and black samples, respectively, which were lower than the AEDR permission limit of $1 \mathrm{mSvy}^{-1}$, as reported by UNSCEAR (2000), except for Hd4 which was about $39 \%$ (1.39 mSv/y) higher than the average value. It was also observed that the AEDR $\mathrm{R}_{\text {indoor }}$ value for $\mathrm{Hd} 1$ and $\mathrm{Hd} 5$ samples were close to the maximum permissible limit. This implies that hair dyes products, if used for multiple times and longer duration may become a source of significant radiological hazards. As compared to the recommended values, the $D_{R}$ value was about 2.41 times higher, while the mean values for each $\mathrm{Ra}_{\mathrm{eq}}$ and $A E D E_{\text {indoor }}$ were less than the recommended level.

In the present study, twenty-four elements ( $\mathrm{Ca}, \mathrm{Na}, \mathrm{Mg}$, $\mathrm{Si}, \mathrm{Al}, \mathrm{K}, \mathrm{Fe}, \mathrm{S}, \mathrm{Ba}, \mathrm{Sr}, \mathrm{Sn}, \mathrm{Sb}, \mathrm{Mo}, \mathrm{Rh}, \mathrm{Ru}, \mathrm{Ti}, \mathrm{Pd}, \mathrm{Pb}, \mathrm{Br}, \mathrm{Ag}, \mathrm{Zn}$, $\mathrm{W}$, In and $\mathrm{Nb})$ and their oxides $\left(\mathrm{Na}_{2} \mathrm{O}, \mathrm{MgO}, \mathrm{Al}_{2} \mathrm{O}_{3}, \mathrm{SiO}_{2}, \mathrm{SO}_{3}, \mathrm{~K}{ }_{2} \mathrm{O}\right.$, $\mathrm{CaO}, \mathrm{TiO}_{2}, \mathrm{Fe}_{2} \mathrm{O}_{3}, \mathrm{ZnO}, \mathrm{SrO}, \mathrm{Bro}, \mathrm{Pbo}, \mathrm{Nb}_{2} \mathrm{O}_{5}, \mathrm{MoO}_{3}, \mathrm{RuO}_{4}$, $\mathrm{Rh}_{2} \mathrm{O}_{3}, \mathrm{PdO}, \mathrm{Ag}_{2} \mathrm{O}, \mathrm{In}_{2} \mathrm{O}_{3}, \mathrm{SnO}_{2}, \mathrm{Sb}_{2} \mathrm{O}_{3}, \mathrm{BaO}$ and $\mathrm{WO}_{3}$ ) were determined. The study revealed that most of the elements present in each dye were higher than the maximum permissible limit (WHO, 2005). Table 3 summarizes the range of mean concentration of elements and their oxides, also it records the lowest and highest values of element concentration in the oxide composition

Singh et al. (2007) reported the toxicological effect and risk evaluation of nanostructured materials on human health and their safety assessment. Human exposure to these materials is inevitable as they can enter the body via drink, food and medicine. They may affect various tissues and organs such as liver, brain, heart, colon, kidney, blood, spleen, bone etc., and may cause cytotoxic effects like inhibition and deformation of cell growth leading to several diseases in humans. Their toxicity grades and interactions with biological systems hugely depend on upon their properties like concentration, size, solubility, stability and biological and chemical properties.

Nagajyoti et al. (2010) investigated the occurrence and toxicity in plants due to accumulation of zinc, cadmium, copper, mercury, chromium, lead, arsenic, cobalt, nickel, manganese and iron. These metals at excessive level are toxic to plants and affect the ecosystem. Sixty-three samples of henna products were analysed by Bernth and Hansen (2005). Pb has been observed in several samples with concentration ranging from $0.00005 \%$ to $0.0002 \%$. Also p-phenylenediamine was observed in three samples varying from $0.003 \%$ to $17 \%$. The highest concentration exceeded the limit stated in the Directive on Cosmetics.

Sulphur and its oxide were recorded in eleven samples. The concentration of sulphur varied from 1.60\% ( $\mathrm{Hd} 14$, black dye) to $98.86 \%$ ( $\mathrm{Hd} 7$ brown dye). The $\mathrm{SO}_{3}$ content ranged from $3.545 \%-99.66 \%$. Highest concentration was reported in brown sample (Hd8) and the lowest value was observed in brown dyes 
Table 3 : The range of mean concentrations of elements and their oxides (\%) hair dyes

\begin{tabular}{|c|c|c|c|}
\hline Element & Range & Oxide & Range \\
\hline $\mathrm{Na}$ & $14.006-45.49$ & $\mathrm{Na}_{2} \mathrm{O}$ & $16.45-38.97$ \\
\hline $\mathrm{Mg}$ & $2.52-32.78$ & $\mathrm{MgO}$ & $3.40-31.79$ \\
\hline $\mathrm{Al}$ & $1.31-13.58$ & $\mathrm{Al}_{2} \mathrm{O}_{3}$ & $1.95-11.28$ \\
\hline $\mathrm{Si}$ & $1.93-40.20$ & $\mathrm{SiO}_{2}$ & $2.923-38.27$ \\
\hline S & $1.60-98.86$ & $\mathrm{SO}_{3}$ & $3.545-99.66$ \\
\hline K & $2.61-34.56$ & $\mathrm{~K}_{2} \mathrm{O}$ & $0.31-15.79$ \\
\hline $\mathrm{Ca}$ & $0.141-85.76$ & $\mathrm{CaO}$ & $0.192-78.75$ \\
\hline $\mathrm{Ti}$ & $0.183-2.98$ & $\mathrm{TiO}_{2}$ & $0.080-4.205$ \\
\hline $\mathrm{Fe}$ & $0.281-10.45$ & $\mathrm{Fe}_{2} \mathrm{O}_{3}$ & $0.075-5.1275$ \\
\hline $\mathrm{Zn}$ & $4.81-28.45$ & $\mathrm{ZnO}$ & $1.04-13.28$ \\
\hline $\mathrm{Br}$ & ND-0.187 & $\mathrm{BrO}$ & ND \\
\hline $\mathrm{Sr}$ & $0.055-0.587$ & $\mathrm{SrO}$ & $0.0368-0.3064$ \\
\hline $\mathrm{Nb}$ & $0.022-0.308$ & $\mathrm{Nb} 2 \mathrm{O} 5$ & $0.0067-0.227$ \\
\hline Mo & $0.0127-0.224$ & $\mathrm{MoO}_{3}$ & $0.0078-0.174$ \\
\hline $\mathrm{Ru}$ & $0.0062-0.115$ & $\mathrm{RuO4}$ & $0.0034-0.0777$ \\
\hline $\mathrm{Rh}$ & $0.0042-0.092$ & $\mathrm{Rh}_{2} \mathrm{O}_{3}$ & $0.0023-0.0547$ \\
\hline $\mathrm{Pd}$ & ND-0.0132 & $\mathrm{PdO}$ & $0.0086-0.0189$ \\
\hline $\mathrm{Ag}$ & $0.0083-0.014$ & $\mathrm{Ag}_{2} \mathrm{O}$ & $0.0064-0.0150$ \\
\hline $\ln$ & $0.0085-0.113$ & $\ln _{2} \mathrm{O}_{3}$ & $0.0031-0.051$ \\
\hline Sn & $0.006-0.067$ & $\mathrm{SnO} 2$ & $0.0027-0.0219$ \\
\hline $\mathrm{Sb}$ & $0.0046-0.055$ & $\mathrm{Sb}_{2} \mathrm{O}_{3}$ & $0.0017-0.0150$ \\
\hline $\mathrm{Ba}$ & $0.73-68.85$ & $\mathrm{BaO}$ & $0.243-53.93$ \\
\hline W & ND-2.02 & $\mathrm{WO}_{3}$ & ND-0.98 \\
\hline $\mathrm{Pb}$ & $0.0215-0.044$ & $\mathrm{PbO}$ & ND \\
\hline
\end{tabular}

ND : Not detectable

sample $(\mathrm{Hd} 14) \mathrm{kg}^{-1}$ where $\mathrm{S}$ concentration in their oxides was $39.91 \%$ and $1.42 \%$, respectively. The concentration of sulphur in the present study exceeded the calculated mean sulphur value of $17.266 \mathrm{mgkg}^{-1}(\approx 0.001726 \%$ ) (Pednekar and Raman, 2013). Sulphur exposure causes skin allergy and irritation of eyes, respiratory, moreover occupational exposure to sulphur has been associated with lung damage (Pean et al.,1995).

Silicon was detected in all the dye samples ranging from $1.93 \%$ to $40.20 \%$, except in $\mathrm{Hd} 6, \mathrm{Hd} 7, \mathrm{Hd} 13$ and $\mathrm{Hd} 17$. Silicon dioxide $\mathrm{SiO}_{2}$ was present in all the samples varying between 2.923-38.27\%, except for Hd6,Hd8, Hd13 and Hd17. All these values exceeded the range value $0.0017-0.10 \%$ of silicon concentrations as reported by Bernth and Hansen (2005). Chang et al. (2007) examined the biological activity of normal fibroblast and tumor cells with varying doses of amorphous silica or composite nanoparticles of silica and chitosan. The silica nanoparticles were found to be nontoxic at low doses while high doses decreased cell viability. High dose of silica also damage cell membrane. The fibroblast cells were more susceptible to damage caused by silica exposure than tumor cells. The silica-chitosan composite nanoparticles caused lower inhibition in cell proliferation, as well as lower membrane damage.

Tin and Antimony were present in all the dye samples, ranging from $0.006 \%$ to $0.067 \%$ and $0.0046 \%$ to $0.055 \%$, except in Hd10, Hd11, Hd12 and Hd16, samples. Tin dioxide and antimony trioxide were noted in all the samples ranging from $0.0027 \%-0.0219 \%$ and $0.0017 \%$ to $0.0150 \%$, respectively, except in $\mathrm{Hd} 9, \mathrm{Hd} 10, \mathrm{Hd} 11, \mathrm{Hd} 12$ and $\mathrm{Hd} 16$. The concentration of $\mathrm{Sn}$ and $\mathrm{Sb}$ was far greater than the range of $\mathrm{Sn}$ $(0.00005-0.000089) \%$ and Sb concentration. The average concentration of In and $\mathrm{Nb}$ varied from $0.0085 \%$ to $0.113 \%$ and $0.022 \%$ to $0.308 \%$. Indium (III) oxide $\left(\operatorname{In}_{2} \mathrm{O}_{3}\right)$ and Niobium pentoxide $\left(\mathrm{Nb}_{2} \mathrm{O}_{5}\right)$ ranged from $0.0031 \%$ to $0.051 \%$ and $0.0067 \%$ to $0.227 \%$ and were detected in all hair dye samples. All the samples accumulated Indium and Niobium elements above mention value (Bernth and Hansen, 2005).

Niobium and its compounds may be toxic, however no reports of human intoxication has been reported. The study on laboratory animals have revealed that inhalation of $\mathrm{Nb}_{2} \mathrm{O}_{5}$ or $\mathrm{NbN}$ leads to fibrosis of lungs at exposure level of $40 \mathrm{mgm}^{-3} . \mathrm{Nb}_{2} \mathrm{O}_{5}$ decompose on heating and emits toxic vapors of niobium (Nowak 
and Ziolek, 1999).

Bromine was only present in sample Hd8 $(0.187 \%)$. Debrah et al. (2011) recorded $\mathrm{Br}$ concentration between BDL to $(0.001395) \%$. Bromine can damage the nervous system and thyroid gland. Few compounds of organic bromine like ethylene bromine are carcinogenic. Tungsten and its trioxide was only reported in sample $\mathrm{Hd} 13$ (2.02\% and $0.98 \%$ ), which was much higher than the range of permissible limit (0.000005-0.000017)\% as reported by Bernth and Hansen (2005). Ruthenium and Rhodium were monitored in all samples except in $\mathrm{Hd} 3$ (blonde hair dye), Hd8 (brown hair dye) and Hd14 (black hair dye). Highest concentration of them was noted in Hd12, whereas lowest value was detected in sample $\mathrm{Hd} 1$. Ruthenium tetroxide $\left(\mathrm{R}_{\mathrm{u}} \mathrm{O}_{4}\right)$ and Rhodium sesquioxide $\left(\mathrm{Rh}_{2} \mathrm{O}_{3}\right)$ were detected in all the samples, except for Hd3, Hd7, Hd14 and Hd15 samples. The highest concentration of $\mathrm{RuO}_{4}$ and $\mathrm{Rh}_{2} \mathrm{O}_{3}$ was found in $\mathrm{H} 16$ $\left(0.0777 \%\right.$ and $0.0547 \%$. The lowest value of $\mathrm{RuO}_{4}(0.0034 \%)$ and $\mathrm{Rh}_{2} \mathrm{O}_{3}(0.0023 \%)$ was noted in $\mathrm{Hd} 1, \mathrm{Mo}$ and $\mathrm{MoO}_{3}$ was present in all samples, except to two black hair dye samples (Hd13 and Hd15), ranging from $0.0127 \%$ to $0.224 \%$ and from $0.0078 \%$ to $0.174 \%$, respectively. However, Mo average concentration exceeded the values reported by Bernth and Hansen (2005), while $\mathrm{MoO}$ accumulated Mo below the limit except, hair dyes samples $\mathrm{Hd} 9, \mathrm{Hd} 10, \mathrm{Hd} 11$, and $\mathrm{Hd} 16$. The $\mathrm{MoO}_{3}$ concentration varied from $0.0078 \%$ (Hd1) to $0.174 \%$ (Hd10). Zinc was found only in two samples $\mathrm{Hd} 13$ and $\mathrm{Hd} 15$ (28.45\% and $4.81 \%)$. $\mathrm{ZnO}$ was noted in Hd7, Hd13 and Hd15 samples (1.040, 13.280\% and $1.041 \%$ ) respectively. Zinc content was lower than the maximum permissible limit of Zn (0.005) \% (Shah et al., 2013). Jeng and Swanson (2006) assessed the toxicity profile of metal nano oxides $\left(\mathrm{ZnO}, \mathrm{TiO}_{2}, \mathrm{Fe}_{3} \mathrm{O}_{4}\right.$ and $\left.\mathrm{Al}_{2} \mathrm{O}_{3}\right)$ in mammalian cells. The microscopic studies showed that nanoparticle-exposed neuro-2A cells were abnormal in size, displaying cellular shrinkage and detachment from the surface of flasks. $\mathrm{ZnO}$ was highly toxic, whereas $\mathrm{Al}_{2} \mathrm{O}_{3}$ was moderately toxic and $\mathrm{Fe}_{3} \mathrm{O}_{4}$ and $\mathrm{TiO}_{2}$ exhibited slight toxicity at high concentration. $\mathrm{Pb}, \mathrm{Ag}$ and Ti metals were present in few samples only. $\mathrm{Pb}$ appeared only in sample Hd11 (0.044\%) and Hd16 $(0.0215 \%)$ which was above the acceptable limit of $\mathrm{Pb}$ in $(0.0005$ $0.001) \%$. PbO was not present in any of the dye samples. Ag was found in sample $\mathrm{Hd} 11(0.014 \%)$ and $\mathrm{Hd} 16(0.0083 \%)$ only. Silver oxide $\left(\mathrm{Ag}_{2} \mathrm{O}\right)$ was found only in sample $\mathrm{Hd} 11(0.0104 \%), \mathrm{Hd} 14$ $(0.0150 \%)$ and $\mathrm{Hd} 16,(0.0064 \%)$. Ag concentration exceeded the permissible limit $(0.000001-0.00008) \%$ as recommended by WHO (2005). Ti was present in four samples $\mathrm{Hd} 3(1.10) \%$, Hd6 (0.183)\%, $\mathrm{Hd} 9(2.54) \%$ and $\mathrm{Hd} 14(2.98) \%$. Titanium dioxide $\left(\mathrm{TiO}_{2}\right)$ was found in sample Hd3 (0.460\%), Hd6 (0.080\%) and Hd14 (4.205\%).

Lead exposure can cause various biological effect depending on the duration and level of exposure. It is one of the most toxic elements that may affect the central nervous system, reproductive system and endocrine system (ATSDR, 1999).

Exposure to titanium may be harmful to brain, where titanium nanoparticles can directly access the brain through olfactory bulb present in the nose. Although titanium dioxide is used as an additive in the pharmaceutical and food products, but on the other hand, it has also been classified as a possible carcinogenic to humans by the International Agency for Research on Cancer (Flamm,1985).

Calcium was observed in all the samples, except for $\mathrm{Hd} 1$, $\mathrm{Hd} 4, \mathrm{Hd} 5$ and $\mathrm{Hd} 13$. Ca content varied from $0.141 \%$ for black hair dye (Hd15) to $85.76 \%$ for blonde hair dye (Hd2). It was observed that the calcium level in hair dye samples exceeded the permissible range $(0.0005-2.40) \%$, except for $\mathrm{Hd} 6, \mathrm{Hd} 7$ and $\mathrm{Hd} 15$ (Bernth and Hansen, 2005). Calcium oxide was present in eleven samples, in range of $0.192 \%-78.75 \%$, except for $\mathrm{Hd} 1, \mathrm{Hd} 4, \mathrm{Hd} 5$, $\mathrm{Hd} 7, \mathrm{Hd} 13$ and $\mathrm{Hd} 15$.

Sodium was observed only in four samples $\mathrm{Hd} 1$ (14.006\%), Hd3 (45.49\%), Hd6 (42.70\%) and Hd7 (22.60\%). $\mathrm{Na}_{2} \mathrm{O}$ was also observed in four samples $\mathrm{Hd} 3, \mathrm{Hd} 6, \mathrm{Hd} 8$ and $\mathrm{Hd} 15$ varied from $16.45 \%-38.97 \% \mathrm{Na}$ level in the hair dyes exceeded the permissible range of $(0.0001-0.5) \%$ (Bernth and Hansen, 2005). The highestAl and $\mathrm{Mg}$ content was found in brown hair dye (Hd9;13.58\%) and black dye (Hd15; $32.78 \%)$, however the lowest content was found in brown hair dye. (Hd10;1.31\%) and in blonde hair dye (Hd2; 2.52\%).

The highest concentration of $\mathrm{Fe}$ and $\mathrm{Sr}$ was observed in brown hair dye sample Hd8 (10.45) \% and (0.587) \% where the lowest concentration were observed in black hair dye sample $\mathrm{Hd} 15(0.281) \%$ and blonde hair dye $\mathrm{Hd} 2(0.055) \%$. The highest $\mathrm{Al}_{2} \mathrm{O}_{3}$ concentration of $11.28 \%$ was found in $\mathrm{Hd}_{2}$ (blonde dyes) and the lowest value was recorded in brown dyes $\mathrm{Hd} 10$ (1.95\%). The concentration of $\mathrm{MgO}$ ranged between $3.40 \%$ ( $\mathrm{Hd} 2)-31.79 \%$ $(\mathrm{Hd} 4)$, while $\mathrm{Fe}_{2} \mathrm{O}_{3}$ ranged between $0.075 \%(\mathrm{Hd} 7)-5.1275 \%$ (Hd14). Strontium oxide (SrO) varied from $0.0368 \%(\mathrm{Hd} 2)$ to $0.3064 \%(H d 16)$.

Huda (2015) evaluated the level of toxic metals in twelve samples of hair dyes from the local store for various brands in Baghdad. The concentration of heavy metals ranged from 0.41 to $0.91 \mathrm{mgkg}^{-1}$ for lead, 0.26 to $0.31 \mathrm{mgkg}^{-1}$ for copper, 0.64 to 1.36 $\mathrm{mgkg}^{-1}$ for iron and 0.11 to $0.16 \mathrm{mgkg}^{-1}$ for cadmium $\left(1 \mathrm{mgkg}^{-1}\right.$ $=0.0001 \%$ ). It is obvious that heavy metals causes skin problems and cancer due to long term exposure.

In regard to $\mathrm{Ba}$ and $\mathrm{BaO}$, all $\mathrm{Ba}$ concentrations in samples were found to be higher than the calculated value $(0.0027-$ 16.7786 ) \% (Ghanjaoui et al. 2014), except in sample Hd3 $(0.73 \%)$, where the highest $\mathrm{Ba}$ concentration was noted in sample $\mathrm{Hd} 12(68.85 \%)$. $\mathrm{BaO}$ was observed in the range of $0.243 \%$ $53.93 \%)$.

Palladium was found only in one sample $\mathrm{Hd} 2(0.0132 \%)$, however, $\mathrm{PdO}$ was detected in two samples $\mathrm{Hd} 2(0.0086 \%)$ and $\mathrm{Hd} 16(0.0189 \%)$. The permissible limit of $\mathrm{Pd}$ is $0.002 \mathrm{mgkg}^{-1}$. All palladium compounds are highly toxic and carcinogenic. It may cause skin sensitization, eye or respiratory tract irritation. In general, people with known palladium allergy should not work with 
palladium compounds. Personal protective equipment should be used to prevent skin contact with palladium compounds, but no specific guideline to palladium exposure has been published (WHO, 2002). Potassium was present in ten samples. The concentration of potassium varied between $2.61 \%$ to $34.56 \%$. Potassium oxide $\left(\mathrm{K}_{2} \mathrm{O}\right)$ was present in nine samples, ranging between $0.31 \%$ to $15.79 \%$.

The results indicate that the toxicity resulting due to regular use of hair dyes can not be ignored.

\section{References}

Abdel Ghany, H.A. and E. M. Ibrahim: Unexpected radiation hazard in dyes of textiles. Isotopes Environ. Hith. Stud., 50, 546-554 (2014).

Abdul Hussein, A. K., H. N. Hady and A. A. Abojassim: Measurement of natural radioactivity in selected samples of medical plants in Iraq. Int. J. Phys. Sci.,11,178-182 (2016).

Agency for Toxic Substances and Disease Registry. Toxicological profile for lead. Atlanta: US Department of Health and Human Services, Public Health Service (1999).

Al-Suwaidi, A. and H. Ahmed : Determination of para-phenylenediamine (PPD) in henna in the United Arab Emirates. Int J. Environ. Res. Public Hlth., 7,1681-93(2010).

Bajoga, A.D., N Alazemi, P.H. Regan and D.A. Bradley : Radioactive investigation of NORM samples from Southern Kuwait soil using high-resolution gamma-ray Spectroscopy. Rad. Physi. Chem.,116, 305-311(2015).

Beretka, J. and P.J. Mathew: Natural radioactivity of Australian building materials, industrial wastes and by products. Hlth. Phys., 48, 87-95(1985)

Bernth, N. and O. C. Hansen: Survey of chemical substances in kohl and henna products. Survey of Chemical Substances in Consumer, Survey No. 65 (2005).

Budaka, G. I. Aslanb, A. Karabuluta and E. Tirasogluc : Analysis of some elements in three Chrysolina (Coleoptera, Chrysomelidae) species by EDXRF spectrometry. J. Quant. Spectro. Rad. Trans., 101,195-200(2006).

Broides, A, S. Sofer and I. Lazar : Contact dermatitis with severe scalp swelling and upper airway compromise due to black henna hair dye. Pediatr. Emerg. Care., 27,745-746(2011).

Chakraborty, S. R., R. Azim, A.K.M.R. Rahman and R. Sarker : Radioactivity concentrations in soil and transfer factors of radionuclides from soil to grass and plants in the Chittagong city of Bangladesh. J. Physi. Scien., 24, 95-113(2013).

Chang, J. S., K.L. Chang, D.F. Hwang and Z.L. Kong : In vitro cytotoxicitiy of silica nanoparticles at high concentrations strongly depends on the metabolic activity type of the cell line. Environ. Sci. Technol., 41, 2064-2068(2007).

Chandrashekara, K. and H.M. Somashekarappa: Estimation of radionuclides concentration and average annual committed effective dose due to ingestion for some selected medicinal plants of South India. J. Radi. Res. Appli. Sci., 9, 68-77 (2016).

Debrah, SK., J.E. Ayivor, D. Denutsui, B.A. Kwofie, A. Forson and C. Nuviadenu : Elemental evaluation of some herbal plants used in Ghana using INAA. Der. Pharma. Chemica., 3, 202-207 (2011).

Fernández-Vozmediano, J.M., M. Padilla-Moreno, J.C. Armario-Hita and C. Carranza-Romero : Pattern of contact sensitization to paraphenylenediamine and its detection in hair dyes. Actas
Dermosifiliograficas, 102, 206 -211 (2011).

Flamm, W.G. : Hair dyes, Laboratory Evidence. IARC Scientific Publications No. 65. International Agency For Research on Cancer, Lyon (1985).

Gaffar, S., M.J. Ferdous, A. Begum and S.M. Ullah : Transfer of natural radionuclides from soil to plants in North Western parts of Dhaka. Malaysian J. Soil Sci.,18, 61-74 (2014).

Ghanjaoui,. M.E., M.L. Cervera, M.El Rhazi and M. de la Guardia : Assessment of trace elements in traditional Moroccan cosmetics by inductively coupled plasma atomic emission spectroscopy. Inte. J. Sci. Technol. Res., 3,104-112(2014).

Haluk, A.H., S. Adatepe, F. Tahan and I. Solmaz: Hair dyes and temporary tattoos are a real hazard for adolescents. Eur. Ann. Allergy Clin. Immunol., 46, 35-37(2014).

Huda, J.H.: Evaluation of the Concentration of some heavy metals in hair dyes in Baghdad. Int. J. Sci. Res., 4, 687-691 (2015).

Jeng, H. A. and J. Swanson : Toxicity of metal oxide nanoparticles in mammalian cells. J. Environ. Sci. Hith, Part A, 41, 2699- 2711 (2006).

Le Coz CJ, C. Lefebvre, F. Keller and E. Grosshans : Allergic contact dermatitis caused by skin painting (pseudotattooing) with black henna,a mixture of henna and p-phenylenediamine and its derivatives. Arch. Dermatol.,136,1515-1517(2000).

Nagajyoti, P. C., K. D. Lee and T. V. M. Sreekanth: Heavy metals, occurrence and toxicity for plants: a review. Environ. Chem. Lett., 8, 199-216(2010).

Nohynek, G.J.. R. Fautz, F. Bench-Kieffer and H. Toutain : Toxicity and human health risk of hair dyes. Food Chem. Toxicol., 42, 517-43 (2004).

Nowak, I and M. Ziolek: Niobium compounds: Preparation, Characterization and application in heterogeneous catalysis. Chem. Rev., 99, 3603-3624 (1999).

Pean, A.R., R.B. Persons, R.H. Waring, A.C. Williams and D.B. Ramsden :Toxicity of sulphur-containing compounds to neuronal cell lines. J. Neurol. Sci.,129, 107-8(1995).

Pednekar, P. and B. Raman.: Multi element determination in methanolic soxhlet in leaf extact of Semecarpus anacardium (LINN.F.) by ICPAES technique. Asian. J. Pharm. Clin. Res., 6, 132-137 (2013).

Pietrzak-Flis, Z., L. Rosiak, M. Suplinska, E. Chrzanowski and S. Dembinska : Daily intakes of 238U, 234U, 232Th, 230Th, 228Th and 226Ra in the adult population of Central Poland. Sci. Total Environ., 27, 163-169 (2001).

Shah, A., A. Niaz, N. Ullah, A. Rehman, M. Akhlaq, M. Zakir and M.S. Khan : Comparative study of heavy Metals in soil and selected medicinal plants. J. Chemi., 2013 (2013). (http://dx.doi.org/ 10.1155/2013/621265).

Saleh, A. and A. El-Taher: Assessment of natural radioactivity level and radiation hazards in soil samples of Wadi Al- Rummah Qassim province, Saudi Arabia. J. Enviro. Biol., 37, 985-991(2016).

Singh, S. and H. S. Nalwa: Nanotechnology and health safety - Toxicity and risk assessments of nanostructured materials on human health. J. Nanosci. Nanotechnol., 7, 3048-3070 (2007).

UNSCEAR : United Nations Scientific Committee on the Effects of Atomic Radiation. Sources, Effects and Risks of lonizing Radiation. Report to the General Assembly with Annex B. United Nations, New York. (2000).

World Health Organization (WHO) : Quality Control Methods for Medicinal Plant Materials, World Health Organization, Geneva, Switzerland (2005).

World Health Organization : Environmental Health Criteria 226, Palladium, World Health Organization, Geneva (2002). 